\title{
Employee performance in Bappeda Palembang as perceived through interpersonal communication and work environment
}

\author{
Yasir Arafat $^{\left.1^{*}\right)}$, Tri Darmawati ${ }^{1}$, Harridlil Mukminin $^{1}$ \\ ${ }^{1}$ Universitas PGRI Palembang, Indonesia
}

\begin{tabular}{l} 
Article Info \\
\hline Article history: \\
Received Mar $30^{\text {th }}, 2021$ \\
Revised Apr $18^{\text {th }}, 2021$ \\
Accepted May $18^{\text {th }}, 2021$ \\
\hline
\end{tabular}

\section{Keyword:}

Interpersonal communication Work environment Performance

\begin{abstract}
The purpose of this study was to determine the effect of interpersonal communication and the work environment on employee performance in Bappeda Palembang. The sample was 40 employees in Bappeda Palembang. The survey for this study is based on 40 workers as respondents. Data were gathered and organized into a list of questions. The SPSS for Windows version 22 was used to analyze the outcomes using simple linear regression analysis, multiple linear regression analyses, t-tests, and f-tests. The interpersonal communication has a partially negative and insignificant effect on employee performance, work environment has a positive and significant effect on employee performance. Furthermore, obtained interpersonal communication as well as the workplace environment have a significant impact on employee performance.
\end{abstract}

(C) 2021 The Authors. Published by IICET.

This is an open access article under the CC BY-NC-SA license

(https://creativecommons.org/licenses/by-nc-sa/4.0)

\section{Corresponding Author:}

Yasir Arafat,

Universitas PGRI Palembang

Email: yasirarafat@universitaspgri-palembang.ac.id

\section{Introduction}

Human resources are the primary motivating force behind an organization's activities; the presence or absence of human resources determines the organization's success or failure. As a result, employees in an organization have become a critical concern in order to achieve organizational success. Employees have an important role in an organization. Employee performance must be optimized and run in accordance with organizational standards. Many factors affect employee performance, and the factors include interpersonal communication and work environment.

In this review, the first factor influencing employee performance is interpersonal communication. According to Sari (2017) interpersonal communication is face-to-face interaction between two or several people, where the sender can convey the message directly and the message recipient can receive and can respond directly (Lusiawati, 2019). Communication is a managerial process for organizations, which includes planning, organizing, leading, and controlling, so it is reasonable to conclude that one of the things that can hinder employee work performance is a lack of effective communication (Yuniar et al, 2020). Many people have forgotten the importance of communication in organizations in this day and age because they are more concerned with their job responsibilities than communicating with other parties in the organization.

Communication, according to (Rahardja, 2004), is a series of actions or events that occur sequentially and are related to one another within a specific time frame. Many factors are involved in carrying out a communication process, and the process of communication activities is actually an activity that is carried out 
consciously, deliberately, and according to the wishes of the perpetrators. A communication process will run smoothly if every step of the process goes smoothly. A positive relationship between performance and interpersonal communication ensures that each stage of the process runs smoothly.

Bappeda Palembang organization implements formal and informal interpersonal communication for all employees who work as a team. Formal communication is typically conducted during a meeting, whereas informal communication is typically conducted during working hours. The Bappeda Palembang organization also provides and maintains a suitable working environment for its employees. The Bappeda Palembang organization provides a special room for its officials as well as adequate workspace for its employees in an effort to provide a good working environment (Putri et al, 2019). Indoor work places employees are aided by several computers, printers, air conditioners that keep the temperature in the room cool, adequate lighting for the employee's work, and coloring that makes employees more comfortable and effective in their work in Bappeda Palembang organization (Ratnasari et al, 2021; Husna \& Huda, 2017).

As social beings, humans always engage in the process of communicating with one another, whether intentionally or unintentionally, in order to meet physical needs. Communication also occurs in an organization or office because employees must communicate with one another in order to carry out routine work tasks. Interpersonal communication is a vital tool for communicating with or receiving information from other people. Communication is also the process of conveying ideas and information from the leadership to employees in the form of orders to ensure that work tasks are completed as efficiently as possible.

One of the theories of interpersonal communication is individual-centered, according to (Budyatna, 2015). This is related to humans' creative nature. How can we hear, say, think, and do if we have never heard, said, or thought before? This is fantastic when we have written new sentences. As a result, interpersonal communication is an interaction, a symbolic process that requires people to regulate their environment by forming human relationships and exchanging information in order to strengthen attitudes and behaviors. Communication serves as a conduit for managerial processes such as planning, organizing, leading, and controlling in organizations.

According to Sari (2017), the delivered communication has the following characteristics 1) Communication is a process; 2) Communication has a goal; 3) Communication occurs when the actors involved cooperate; 4) Communication is symbolic; 5) Communication is transactional; and 6) Communication transcends time and space. Based on the aforementioned communication characteristics, communication can be defined as a series of acts or events that occur sequentially and are linked to one another over time. Many factors are involved in the communication process, including communication actors, messages (content, presentation method), the media used, time, place, and the results or consequences that occur after the communication process. Furthermore, communication activities are usually carried out consciously and deliberately, or with the cooperation of the actors involved, and are tailored to the perpetrators' wishes and goals. As a result of the sophistication of current technology, messages are conveyed in the communication process using symbols, symbols, verbal and nonverbal language, so that they are transactional by each actor penetrating space and time.

According to Sari (2017), interpersonal communication can take place at various stages of the process, including contact, introduction, friendship, conflict, and division. Interpersonal communication is essentially the creation and maintenance of relationships, as well as how partners (actors in communication) overcome normal and extraordinary challenges in order to maintain communication intimacy at all times. Among the indicators contained in interpersonal communication are: 1) participants involved in communication, 2) the communication process, and 3) communication symbols (Afriyadi, 2015).

Another factor that influences employee success is the work environment. According to Rahmawanti, Swasto, \& Prasetya (2014) the working environment is an essential component of employees' work. The workplace is where employees go every day to do their jobs. Employees are said to be in a good work environment if they perform their tasks well, feel safe, and are relaxed. Furthermore, the level of job output is affected by the working environment. A pleasant work environment and effective interpersonal contact may have an impact on employee performance. According to Permanasari (2013), performance is a genuine job accomplishment or achievement that employees can achieve. Furthermore, performance is the result of work done over time in comparison to various possibilities, such as mutually agreed-upon expectations, goals, or requirements.

The work environment is one of the most important factors to consider. Even if the work environment does not directly affect the workers who carry out the manufacturing process in an organization, it does have an impact on them. Employee performance can be enhanced by providing an acceptable work environment, whereas employee performance can be harmed by providing an inadequate work environment. 
The work environment is also referred to as the location where employees perform their daily tasks. Employees are said to be in a good work environment if they perform their tasks well, feel safe, and are relaxed. According to Siswanto and Yuniawan (2012), the working environment is the world in which people work and how it affects how they perform a mission or a job. Individuals in a company regard their work environment as an attribute that they use to embody their existence within the organization.

According to (Prihantoro, 2019), the work environment is everything that surrounds the workforce and can affect his ability to complete the tasks assigned to him. The work environment is divided in two sections, the internal work environment and the external work environment. According to Sedarmayanti (2017) the workplace is divided into two parts: a physical work-place atmosphere, and a social work-place environment that includes all working conditions outside the workplace that can affect the workforce directly or indirectly. To achieve a safe working environment, attention must be paid to the aid in the physical working environment (Indiyati, 2020; Theorell, 2015). Building maintenance, workspace and ambient temperature, ventilation, noise, color, workplaces, and cleanliness all have an impact on the physical working environment; Nonphysical work environment. Designing a non-physical work environment is actually more difficult than designing a physical work environment. This is due to heterogeneous human nature and changes that can occur quickly in humans, causing the design or design of this non-physical work environment to be inaccurately calculated. Based on the foregoing, the work environment indicators include: 1) employee relations, 2) work atmosphere, and 3) employee work facilities.

To achieve organizational goals, which must be accompanied by excellent performance from all employees. According to Sedarmayanti (2017), performance is a record of the results produced for specific work activities over time. Not characteristics and habits, but performance as a result of those characteristics and habits. Furthermore, progress refers to a person or group of individuals working in an association on the basis of its respective authorities and responsibilities to achieve the organization's goals in a legally, lawfully, socially, and ethically sound manner. Job and work success according to Kasmir (2016), derive from the completion of tasks and responsibilities assigned within a given timeframe. Employee performance, according to (Prihantoro, 2019), is the outcome of work over time compared to different options, such as mutually agreed-upon expectations, goals, or requirements.

\section{Method}

According to Sugiyono (2017), the mind frame is a model of how hypothesis have been established as significant influences. A positive frame of mind will explain the theoretical relationships between the variables to be investigated. The relationship between the independent and dependent variables must also be explained logically. The basis for reasoning in this analysis is interpersonal communication (X1) and the working environment (X2) as independent variables and employee performance $(\mathrm{Y})$ as dependent variables.

In this study, interpersonal communication variables and the work environment are referred to as (independent variables) variable $\mathrm{X}$, and they are variables that are independent of other variables. While the performance variables in this study, referred to as the dependent variable with a variable $\mathrm{Y}$, are variables that are dependent on or affected by other variables. According to the findings of the study (Julita \& Arianty 2018), interpersonal communication and working environments have a significant impact on performance in part and concurrently. This is also supported by the findings (Fachrezi \& Khair, 2020) that interpersonal communication and the working environment have a significant impact on performance at the same time. A provisional assumption or hypothesis is derived from the above-mentioned framework of thought and theory: 1) It is suspected that interpersonal communication has an effect on the performance of Bappeda Palembang employees; 2) It is suspected that the work environment has an effect on the performance of Bappeda Palembang employees; and 3) It is suspected that interpersonal communication and the work environment both have an effect on the performance of Bappeda Palembang employees. The image below depicts the study's frame of mind. 


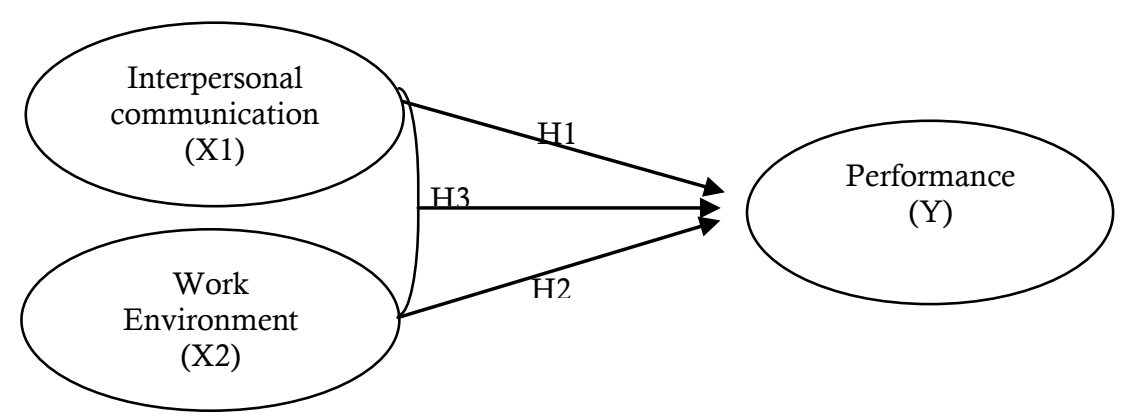

Figure 1. Research framework

This study included 40 people from the Bappeda Palembang. The saturated sample technique was used in this study to determine the sample. As a result, the number of samples is the same as the population, which could be as many as 40 people. This is a quantitative study that uses questionnaires and documents to collect data. The assessment scale for this study is a Likert scale, which is used to assess an individual's or a group's beliefs, views, and impressions of social phenomena. Using a Likert scale, the variables to be evaluated are converted into indicator variables. These markers are then used as a jumping off point for creating instrument pieces, which can take the form of statements or queries. Using computerized SPSS 22.0 for Windows software, the questionnaire was reviewed with the following data:

Table 1. Validity Test Results

\begin{tabular}{|c|c|c|c|c|c|}
\hline No & Statement & $\mathbf{r}_{\text {count }}$ & $\mathbf{r}_{\text {table }}$ & criteria & Information \\
\hline \multicolumn{6}{|c|}{ Interpersonal Comunication Variable } \\
\hline 1 & statements 1 & $0,507^{\star *}$ & 0,312 & $\mathrm{r}_{\text {count }}>$ tabel $\mathrm{r}$ & Valid \\
\hline 2 & statements 2 & $0,614^{* *}$ & 0,312 & $\mathrm{r}_{\text {count }}>$ tabel $\mathrm{r}$ & Valid \\
\hline 3 & statements 3 & $0,652^{* *}$ & 0,312 & $\mathrm{r}_{\text {count }}>$ tabel $\mathrm{r}$ & Valid \\
\hline 4 & statements 4 & $0,498^{* *}$ & 0,312 & $r_{\text {count }}>$ tabel $r$ & Valid \\
\hline 5 & statements 5 & $0,532^{* *}$ & 0,312 & $\mathrm{r}_{\text {count }}>$ tabel $\mathrm{r}$ & Valid \\
\hline 6 & statements 6 & $0,481^{* *}$ & 0,312 & $\mathrm{r}_{\text {count }}>$ tabel $\mathrm{r}$ & Valid \\
\hline \multicolumn{6}{|c|}{ Work Environment Variable } \\
\hline 1 & statements 1 & $0,603^{* *}$ & 0,312 & $\mathrm{r}_{\text {count }}>$ tabel $\mathrm{r}$ & Valid \\
\hline 2 & statements 2 & $0,481^{\text {** }}$ & 0,312 & $\mathrm{r}_{\text {count }}>$ tabel $\mathrm{r}$ & Valid \\
\hline 3 & statements 3 & $0,608^{* *}$ & 0,312 & $\mathrm{r}_{\text {count }}>$ tabel $\mathrm{r}$ & Valid \\
\hline 4 & statements 4 & $0,553^{* *}$ & 0,312 & $\mathrm{r}_{\text {count }}>$ tabel $\mathrm{r}$ & Valid \\
\hline 5 & statements 5 & $0,617^{* *}$ & 0,312 & $\mathrm{r}_{\text {count }}>$ tabel $\mathrm{r}$ & Valid \\
\hline 6 & statements 6 & $0,458^{* *}$ & 0,312 & $\mathrm{r}_{\text {count }}>$ tabel $\mathrm{r}$ & Valid \\
\hline \multicolumn{6}{|c|}{ Performance Variable } \\
\hline 1 & statements 1 & $0,473^{* *}$ & 0,312 & $\mathrm{r}_{\text {count }}>$ tabel $\mathrm{r}$ & Valid \\
\hline 2 & statements 2 & $0,765^{* *}$ & 0,312 & $r_{\text {count }}>$ tabel $r$ & Valid \\
\hline 3 & statements 3 & $0,527^{\star \star}$ & 0,312 & $\mathrm{r}_{\text {count }}>$ tabel $\mathrm{r}$ & Valid \\
\hline 4 & statements 4 & $0,592^{* *}$ & 0,312 & $\mathrm{r}_{\text {count }}>$ tabel $\mathrm{r}$ & Valid \\
\hline 5 & statements 5 & $0,653^{* *}$ & 0,312 & $\mathrm{r}_{\text {count }}>$ tabel $\mathrm{r}$ & Valid \\
\hline 6 & statements 6 & $0,622^{* *}$ & 0,312 & $\mathrm{r}_{\text {count }}>$ tabel $\mathrm{r}$ & Valid \\
\hline
\end{tabular}

Based on the above validity test results, the results of a questionnaire object in each variable $r$ count $>$ table $r$ can be inferred that both are correct and can be used for further research as a measurement instrument.

Table 2. Reliability test results

\begin{tabular}{lcc}
\hline \multicolumn{1}{c}{ Variable } & Cronbach's Alpha & N of Statement \\
\hline Interpersonal communication & 712 & 6 \\
\hline Work environment & 717 & 6 \\
\hline Performance &, 744 & 6 \\
\hline
\end{tabular}


Based on the above results, which show that the Cronbach's Alpha value is greater than 0.60 , it can be concluded that the measuring instrument used in this study is reliable and can be used as a measuring tool for further analysis.

Table 3. Multicollinearity Test Results

\begin{tabular}{llrrrrr}
\hline & \multicolumn{2}{c}{ UC } & SC & \multicolumn{2}{c}{ CS } \\
\cline { 2 - 6 } Model & \multicolumn{1}{c}{ B } & Std. Error & Beta & Tolerance & VIF \\
\hline 1 & (Constant) & 21,850 & 5,674 & & \\
& Interpersonal communication &,- 299 &, 171 &,- 264 &, 977 & 1,024 \\
& Work environment &, 426 &, 178 &, 362 &, 977 & 1,024 \\
\hline
\end{tabular}

It is assumed that the value for communication tolerances is $0.977>0.10$ and the value for VIF is 1.02410 . Based on the aforementioned findings. Aside from the working environment resistance of $0.977>0.10$ and VIF 1.02410, it is also possible to conclude that the independent variables are not multicollinear. Multicoloniality testing seeks to determine whether a relationship exists between the independent variables in the regression model (independent). When an association exists, this is referred to as multi-linearity. A strong regression model should show no association between independent variables. It is possible to detect signs of multicollinearity using the VIF value.



Figure 2. Heteroscedasticity test

It explains, based on the above equations' results, that no simple trend exists, such as the points on the $y$ axis above and below number 0 . As a result of the regression model, it is possible to conclude that there is no evidence of heteroscedasticity. The heteroscedasticity test determines whether the variances of the residuals between observations are unequal in the regression model. If the difference between observations is constant, it is referred to as homoscedasticity; otherwise, it is referred to as heteroscedasticity.

Table 4. Normality Test One-Sample Kolmogorov-Smirnov Test

\begin{tabular}{|c|c|c|}
\hline \multicolumn{3}{|c|}{ Unstandardized Residual } \\
\hline $\mathrm{N}$ & & 40 \\
\hline Normal Parameters ${ }^{\mathrm{a}, \mathrm{b}}$ & Std. Deviation & 1,94983919 \\
\hline Test Statistic & &, 103 \\
\hline Asymp. Sig. (2-tailed) & & $200^{\mathrm{c}, \mathrm{d}}$ \\
\hline
\end{tabular}

a. Test distribution is Normal.

According to the performance of table 4, the importance value (Asymp. Sig 2-tailed) is 0.200. When the significant value is greater than 0.05 , the residual value is usually distributed. As a result, the interpersonal communication indicator questionnaire, work environment, and results will all be used as a metric for additional research.

\section{Results and Discussions}

Based on the table 6 and the simple linear regression results, the regression coefficient for interpersonal communication is -0.237 and the constant is 30.879 , resulting in the following simple linear regression equation: In addition to $\mathrm{Y}=30.879-0.237 \mathrm{X} 1$, The $\mathrm{t}$-value for the interpersonal communication variable on performance was t-count 1.320, which was less than the t-table 1.685, implying that partially interpersonal communication has a negative and insignificant effect on employee performance. This contradicts existing theories and previous research findings. This could be due to other factors that have a greater influence on performance. 
Table 5. The results of simple linear regression $X_{1}$ against $Y$

\begin{tabular}{|c|c|c|c|c|c|}
\hline \multirow[b]{2}{*}{ Model } & \multicolumn{2}{|c|}{$\mathrm{UC}$} & \multirow{2}{*}{$\frac{\mathrm{SC}}{\text { Beta }}$} & \multirow[b]{2}{*}{$\mathrm{T}$} & \multirow[b]{2}{*}{ Sig. } \\
\hline & $\mathrm{B}$ & Std. Error & & & \\
\hline $1 \quad$ (Constant) & 30,879 & 4,485 & & 6,885 &, 000 \\
\hline Interpersonal communication &,- 237 & 180 &,- 209 & $-1,320$ & 195 \\
\hline
\end{tabular}

a. Dependent Variable: performance

Interpersonal communication, on the other hand, has a negative but insignificant effect on performance. Interpersonal communication, according to Rezaka \& Waskito (2016), is an interaction, a symbolic process that requires people to regulate their environment by building human relationships through information exchange to strengthen attitudes and behaviors. As a result, it is suspected that interpersonal communication at the Palembang City Bappeda currently has a negative but insignificant effect on employee performance.

Table 6. Simple linear regression results of $\mathrm{X}_{2}$ to $\mathrm{Y}$

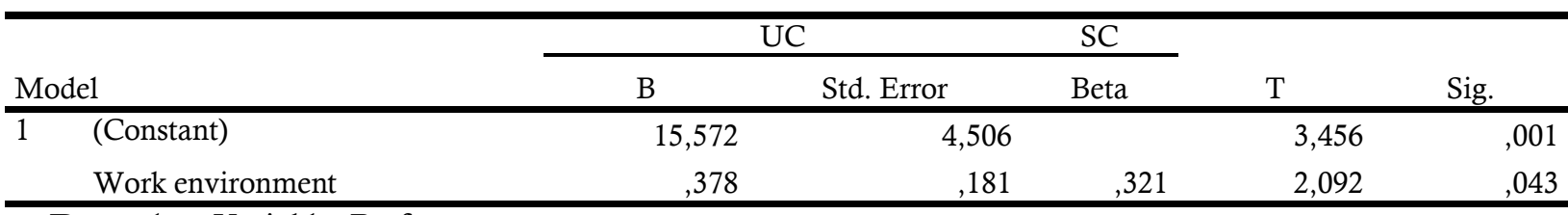

a. Dependent Variable: Performance

Based on the table above, the simple linear regression results show that the regression coefficient for the Work Environment is 0.378 and the constant is 15.572 , resulting in the following simple linear regression equation: $\mathrm{Y}=15.572+0.378 \mathrm{X} 2$, and because the $\mathrm{t}$ value for the work environment variable on performance tcount 2.092 is greater than the ttable 1.685, it can be concluded that the work environment has a significant positive effect on employee performance in part. This is consistent with existing theories and research findings.

Table 7. Results Regression Line of Multipleier $\mathrm{X}_{1}$ and $\mathrm{X}_{2}$ to $\mathrm{Y}$

\begin{tabular}{|c|c|c|c|c|c|}
\hline \multirow[b]{2}{*}{ Model } & \multicolumn{2}{|c|}{ UC } & \multirow{2}{*}{$\frac{\mathrm{SC}}{\text { Beta }}$} & \multirow[b]{2}{*}{$\mathrm{T}$} & \multirow[b]{2}{*}{ Sig. } \\
\hline & $\mathrm{B}$ & Std. Error & & & \\
\hline $1 \quad$ (Constant) & 21,850 & 5,674 & & 3,851 &, 000 \\
\hline Communication Interpersonal &,- 299 &, 171 &,- 264 & $-1,546$ & ,089 \\
\hline Environment working & ,426 &, 178 & ,362 & 2,388 & ,022 \\
\hline
\end{tabular}

a. Dependent Variable: Performance

The regression coefficient for interpersonal communication is -0.299 , and the regression coefficient value for the work environment is 0.426 , according to the results of the calculation of multiple linear regression coefficients shown in the table above. In addition to the constants of 21.850 based on the value of the multiple linear regression equation, which are as follows: $\mathrm{Y}=21.850-0.299 \mathrm{X} 1+0.4262 \mathrm{X} 2$

Based on the t-value above, compare the t-value to the t-table to test the effect of each independent variable on the dependent variable. The value of t-table $\mathrm{N}=40-2=38$ and alpha 0.05 is 1.685 , so the t-test is as follows:

a. $\mathrm{X}_{1}=\mathrm{t}_{\text {count }}-1.546$ so that $<\mathrm{t}_{\text {table }} 1.685$ with a significance value greater than 0.05 , was 0.089 .

b. $\mathrm{X}_{2}=\mathrm{t}_{\text {count }} 2.388 \mathrm{so}>\mathrm{t}_{\text {table }} 1.685$ with a significance value smaller than 0.05 , was 0.022 ,

This means that interpersonal communication has a marginally negative and insignificant effect on performance, whereas the work environment has a significant positive effect.

Table 8. "F ANOVA" test ${ }^{\mathrm{a}}$

\begin{tabular}{llrrrrr}
\hline Model & Sum of Squares & Df & Mean Square & F & Sig. \\
\hline 1 & Regression & 30,702 & 2 & 15,351 & 3,831 &, $031^{b}$ \\
& Residual & 148,273 & 37 & 4,007 & & \\
& Total & 178,975 & 39 & & & \\
\hline
\end{tabular}

a. A dependent variable is performance.

b. Predictors: (constant), interpersonal communication, work environment 
In the table above, the F-count is 3.831, resulting in an F-table of 3.24 and a significance value of $(0.031$ 0.05). According to the F-count results and significant meaning, the interpersonal communication variable (X1) and the work environment (X2) both have a positive and significant impact on performance. This is supported by the findings of (Bahri, 2018), (Elizar \& Tanjung, 2018), (Arianto, 2013), (Elizar \& Tanjung, 2018), (Nisa et al., 2018), (Rooswidjajani et al., 2018), (Fristin et al., 2018).

\section{Conclusions}

According to the study's findings, interpersonal communication (X1) has a negative and negligible impact on employee performance (Y). Furthermore, the work environment (X2) has a significant positive impact on employee performance (Y). Interpersonal communication, as well as the work environment, have a significant positive impact on employee performance. As a result, it is suggested that Bappeda Palembang pay more attention to the work environment so that every employee feels relaxed and secure when performing tasks designed to improve employee performance. The purpose of this study is to investigate how interpersonal communication and the work environment affect employee performance partially and simultaneously. To assess the impact of interpersonal communication and the work environment on employee performance, various analyses and assessments can be used. The findings in this article state that while interpersonal communication has a negative and minor impact on employee success, the work environment has a significant impact. Conversely, interpersonal communication and the work environment have a significant positive impact on employee success.

\section{Acknowledgments}

We would like to express our gratitude to the Bapedda Palembang organization, the Chancellor of Universitas PGRI Palembang, the Dean of the Universitas PGRI Palembang Faculty of Economics, and the Universitas PGRI Palembang, Management Study Program for providing opportunities and resources to complete this research project. This research project is supported by private funds. Furthermore, we would like to thank our fellow lecturers in the Management Department for their assistance in completing this research project on time.

\section{References}

Afriyadi, F. (2015). The Effectiveness of Interpersonal Communication between Bosses and Subordinates of PT. Borneo Enterprsindo Samarinda. EJournal of Communication Studies , 3 (1), 362-376.

Arianto, D. A. (2013). Pengaruh Kedisiplinan, Lingkungan Kerja dan Budaya Kerja terhadap Kinerja tenaga pengajar. Jurnal Economia, Vol 9(No. 2), 191-200.

Bahri, A. N. (2018). Peran Komunikasi Antarpribadi pada Lingkungan Kerja dalam Perspektif Islam. Jurnal ilmiah sosiologi agama (JISA), Vpl.1(No.1), 128-142.

Budyatna, M. (2015). Teori-teori mengenai komunikasi antarpribadi [Theories regarding interpersonal communication]. Jakarta: Prenadamedia grup.

Elizar, \& Tanjung, H. (2018). Pengaruh Pelatihan, Kompetensi, Lingkungan Kerja terhadap Kinerja Pegawai. Maneggio: Jurnal Ilmiah Magister Manajemen, Vol.1(No.1), 46-58.

Fachrezi, H., \& Khair, H. (2020). Pengaruh Komunikasi, Motivasi dan Lingkungan Kerja Terhadap Kinerja Karyawan Pada PT. Angkasa Pura II (Persero) Kantor Cabang Kualanamu. Maneggio: Jurnal Ilmiah Magister Manajemen, Vol. 3(No.1), 107-119.

Husna, I., \& Huda, M. (2017). Pengaruh Fasilitas Pembelajaran Terhadap Kedisiplinan Santri di Madarasah Diniyah Muzamzamah Chosyi'ah Asrama Putri XI Pondok Pesantren Darul 'Ulum Jombang. Jurnal Pendidikan Islam, 1(1), 54-75.

Julita, \& Arianty, N. (2018). Pengaruh komunikasi dan lingkungan kerja terhadap kinerja karyawan pada Jasa Marga. Cabang Belmera Medan [The influence of communication and work environment on employee performance at Jasa Marga. Belmera Medan Branch]. Seminar Nasional Multidisiplin Ilmu (hal. 195-205). Medan: Universitas Asahan.

Indiyati, D. (2020). Pengaruh Lingkungan Kerja Fisik Dan Non Fisik Terhadap Kinerja Karyawan Pada Sektor Jaminan Sosial Nasional (studi Kasus Bpjs Ketenagakerjaan [The Effect of Physical and NonPhysical Work Environments on Employee Performance in the National Social Security Sector]. eProceedings of Management, 7(2).

Kasmir. (2016). Manajemen sumber daya manusia teori dan praktek [Human resource management theory and practice]. Jakarta: Raja Grafindo. 
Lusiawati, I. (2019). Public Service in Interpersonal Communication. International Journal for Educational and Vocational Studies, 1(5), 484-488.

Nisa, I. C., Rooswidjajani, \& Fristin, Y. (2018). Pengaruh komunikasi dan lingkungan kerja fisik terhadap kinerja karyawan. Jurnal Bisnis dan Manajemen, Vol. 2(No. 2), 198-203.

Permanasari, R. (2013). Pengaruh motivasi dan lingkungan kerja terhadap kinerja. [The influence of motivation and work environment on the performance]. Managemen analysis journal, Vol. 2(No.2), 1-9.

Prihantoro, A. (2019). Peningkatan kinerja sumber daya manusia melalui motivasi, disiplin, lingkungan kerja dan komitmen. (Studi kasus madrasah di lingkungan yayasan Salafiah, Kajen, Margoyoso, Pati) [Improving the performance of human resources through motivation, discipline, work environment and commitment. (Case study of madrasa within the Salafiah foundation, Kajen, Margoyoso, Pati)]. Yogyakarta: Deepublish.

Putri, E. M., Ekowati, V. M., Supriyanto, A. S., \& Mukaffi, Z. (2019). The effect of work environment on employee performance through work discipline. International Journal of Research-Granthaalayah, 7(4), 132140.

Rahardja, A. T. (2004). Hubungan antara komunikasi antar pribadi guru dan motivasi kerja guru dengan kinerja guru SMUK BPK Penabur Jakarta [The relationship between teacher interpersonal communication and teacher work motivation with teacher performance at BPK Penabur Jakarta Senior High School]. Jurnal Pendidikan Penabur, Vol. III(No. 3), 1-21.

Rahmawanti, N. P., Swasto, B., \& Prasetya, A. (2014). Pengaruh lingkungan kerja terhadap kinerja karyawan (Studi pada karyawan kantor pelayanan pajak pratama Malang utara) [The influence of the work environment on employee performance (Studies on employees of the Pratama tax service office in North Malang)]. Jurnal Administrasi Bisnis, Vol. 8(No. 2), 1-9.

Ratnasari, S. L., Nasrul, H. W., Nurdin, I., Susilowati, Y., \& Susanti, E. N. (2021, June). Analysis of Organizational Commitment, Motivation, Work Ability, and the Working Environment to Employees Performance in the Covid-19 Era. In Sixth Padang International Conference On Economics Education, Economics, Business and Management, Accounting and Entrepreneurship (PICEEBA 2020) (pp. 540-544). Atlantis Press.

Rezaka, K. B., \& Waskito, J. (2016). Pengaruh komunikasi dan lingkungan kerja terhadap kinerja karyawan di perusahaan Bimatex. Surakarta: Universitas Muhammadiyah Surakarta.

Sari, A. A. (2017). Komunikasi Antarpribadi [Interpersonal Communication]. Yogyakarta: Deepublish.

Sedarmayanti. (2017). Perencanaan dan pengembangan sumber daya manusia [Human resource planning and development]. Bandung: PT. Refika Aditama.

Siswanto, E. A., \& Yuniawan, A. (2012). Analisis pengaruh iklim kerja dan pengembangan karir terhadap komitmen karir: kepuasan kerja sebagai variabel intervening [Analysis of the influence of work climate and career development on career commitment: job satisfaction as an intervening variable]. Diponegoro Business Review, Vol. 1(No. 2), 332-342.

Sugiyono. (2017). Metode penelitian kuantitatif, kualitatif, dan $R \& D$ [Quantitative, qualitative, and $R \& D$ research methods]. Bandung: Alfabeta.

Theorell, T., Hammarström, A., Aronsson, G., Bendz, L. T., Grape, T., Hogstedt, C., \& Hall, C. (2015). A systematic review including meta-analysis of work environment and depressive symptoms. BMC public health, 15(1), 1-14.

Yuniar, R. R., Juliawati, D., Jamin, A., \& Yandri, H. (2020). Interpersonal communication analysis of students at Schools that use social media in the New Normal Era. Jurnal Bikotetik (Bimbingan dan Konseling: Teori dan Praktik), 4(2), 41-45. 